\title{
"A Debt Justly Due": The Relief of Civil War Soldiers and Their Families in Dubuque
}

\author{
RUSSELL L. JOHNSON
}

IN HER ANALYSIS of "the idea of poverty" in early industrial England, Gertrude Himmelfarb argues that there have been a number of "decisive turning points" in the history of poverty and poor relief. "On each of these occasions," she adds, "the new condition was soon assimilated into the old, made to seem eminently natural, yet another variation on the eternal phenomenon of the poor who are 'always with you.'" The Civil War might be seen as one of those "turning points" in the history of poor relief in the United States. Two new, large groups demanded the attention of those interested in poor relief: soldiers and their families. Eventually, both groups were, to use Himmelfarb's term, "assimilated" into existing poor relief systems. Private charitable organizations, which had traditionally emphasized aid to the "worthy" poor - those whose poverty was no fault of their own-increasingly turned their attention to the provisioning of soldiers in the field. Soldiers' families meanwhile passed into the care of public poor relief systems, which traditionally took care of the "unworthy" poor or "paupers" -

I presented a portion of this article at Iowa Heritage Expo in June 1995. I want to acknowledge the persons attending that session, especially George McJimsey, as well as Shelton Stromquist, Linda Kerber, and the editors and reviewers of the Annals of Iowa for their contributions to making this a better article.

THE ANNALS OF IOWA 55 (Summer 1996). CThe State Historical Society of Iowa, 1996. 
those whose poverty was seen as the product of some personal moral failure such as indolence or vice. ${ }^{1}$

Historians of Civil War relief have focused on what one calls "warwork" - what I prefer to call the patriotic provisioning of soldiers in the field - carried on by women across the country under the auspices of national organizations such as the United States Sanitary Commission and the Christian Commission. These efforts were indeed impressive. Guided by the Sanitary and Christian Commissions, benevolent organizations and individuals across the North devoted their efforts to soldiers in the field - \$15 million worth via the Sanitary Commission alone, according to one postwar estimate. For the most part, however, historians have ignored the other war work, the efforts on behalf of soldiers' families. ${ }^{2}$

In many ways, the historiography merely reflects what happened during the war itself. Despite assurances when the soldiers left home that their families would not be allowed to suffer in their absence, provisioning work increasingly consumed the attention of private benevolent organizations, while soldiers' families were gradually shifted to public relief systems and forgotten. Attention to provisioning work has also led historians to show greater interest in the aid donors than the recipients.

1. Gertrude Himmelfarb, The Idea of Poverty: England in the Early Industrial Age (New York, 1984), 18. For discussion of nineteenth-century ideas about poverty, see Walter I. Trattner, From Poor Law to Welfare State: A History of Social Welfare in America, 4th ed. (New York, 1989), 50-63; Michael B. Katz, In the Shadow of the Poorhouse: A Social History of Welfare in America (New York, 1986), esp. 3-66; Eric H. Monkkonen, "Nineteenth-Century Institutions: Dealing with the Urban 'Underclass,'” in Michael B. Katz, ed., The "Underclass" Debate: Views from History (Princeton, NJ, 1993), 334-65; and Christine Stansell, City of Women: Sex and Class in New York, 1789-1860 (New York, 1986), 65-71.

2. Jeanie Attie, "Warwork and the Crisis of Domesticity in the North," in Catherine Clinton and Nina Silber, eds., Divided Houses: Gender and the Civil War (New York, 1992), 247-59. For some other examples of the growing body of literature on warwork, see George M. Fredrickson, The Inner Civil War: Northern Intellectuals and the Crisis of the Union (New York, 1965), 98-112; Robert H. Bremner, The Public Good: Philanthropy and Welfare in the Civil War Era (New York, 1980); and Elizabeth D. Leonard, Yankee Women: Gender Battles in the Civil War (New York, 1994). For family relief, one has to turn to much older publications, such as Carl R. Fish, "Social Relief in the Northwest during the Civil War," American Historical Review 23 (1917), 309-24; and Dixon Wector, When Johnny Comes Marching Home (Cambridge, MA, 1944), esp. 161-62. 
Thus, although middle- and upper-class women may have, in one scholar's words, "chipped away at the ideology of domesticity" through their involvement in war relief work, historians have failed to see the way relief promoted domesticity among the recipients. ${ }^{3}$ And in general, historians have failed to relate war relief efforts to the broader context of poor relief in the United States.

An examination of relief to soldiers and their families in a single community offers the best way to begin to illuminate this important subject. The city chosen for this analysis is Dubuque, Iowa. Founded in the 1830 s as a lead mining community, by 1860 Dubuque was the largest city in Iowa and the eightieth largest in the nation. Commercial expansion during the mid1850 s seemed to have established Dubuque as the "Key City" for trade in a large region to the west and north. But the city had reached the limits of commercial capitalist growth, a fact exposed, first, by the Panic of 1857 and then by the suspension of Mississippi River traffic after southern secession in 1861. Further economic growth, many in the city recognized, would require the mobilization of capital and labor for industrial development. Nationally, Dubuque was one of many cities that reached this developmental crossroads at mid-century.

3. Attie, "Warwork," 248. For a contrary opinion about the ideology surrounding women's war work, see J. Matthew Gallman, Mastering Wartime: A Social History of Philadelphia during the Civil War (New York, 1990), esp. 165-66; Gallman emphasizes continuity rather than change in that ideology. Oddly, however, Gallman's richly detailed analysis of Civil War-era Philadelphia fails to even mention family relief, although he does devote an entire chapter to the Philadelphia Sanitary Fair, an exercise in patriotic provisioning.

4. The early history and economic development of Dubuque are covered more fully in my dissertation, "An Army for Industrialization: The Civil War and the Formation of Urban-Industrial Society in a Northern City" (Ph.D. diss., University of Iowa, 1996). Some important secondary sources include William J. Peterson, "The Eldorado of Iowa," Palimpsest 45 (1964), 401-8; William E. Wilkie, Dubuque on the Mississippi (Dubuque, 1987), 46-63, 76-98; and Timothy R. Mahoney, "Urban History in a Regional Context: River Towns on the Upper Mississippi, 1840-1860," Journal of American History 72 (1985), 322-25. For population and relative industrial development, see U.S. Department of Commerce, Bureau of the Census, Eighth Census of the United States, 1860 (Washington, DC, 1866) 4:xviii-xix. For patterns of industrialization during the century, see Walter Licht, Industrializing America: The Nineteenth Century (Baltimore, 1995). 
Although Dubuque reflected national economic trends, it was also unique in certain ways. Most importantly, it remained steadfastly Democratic in politics while most of Iowa turned to the Republican Party during the late 1850s. The Civil War further reinforced Dubuque's political difference within Iowa and in the Union. Most of the city's leading Democrats came out in opposition to the war, earning the city a national reputation as "a Secession hole" and prompting the federal government to arrest and briefly imprison two of its citizens, former U.S. Senator George Wallace Jones and newspaper editor Dennis Mahony. ${ }^{5}$

Partisan politics, however, seem less important than general prewar attitudes toward the poor and poor relief in determining local responses to soldiers and their families. When initial voluntary efforts on behalf of soldiers' families failed, for example, the first voice to call for action by the state government was Dennis Mahony's. By 1863, both war supporters and opponents showed markedly less interest in the welfare of soldiers' families, but both could be found enlisting in the cause of patriotic provisioning. The rhetorics of provisioning and family aid also differed. Few, regardless of their opinions about the war itself, thought the soldiers anything but "worthy" of relief. Increasingly rare were the community leaders or spokespersons who thought the same about the families. ${ }^{6}$

Then, in 1864, Dubuque's Ladies Aid Society, the largest and most prominent war relief organization in the city, turned

5. For Dubuque as "a Secession hole," see Philadelphia Press, quoted in Dubuque Daily Times, 21 January 1862 . Hereafter all newspapers are Dubuque dailies, unless otherwise noted. For brief, politically slanted, descriptions of the arrest and incarceration of Jones and Mahony, see John A. Marshall, American Bastile: A History of the Illegal Arrests and Imprisonment of American Citizens during the Late Civil War (Philadelphia, 1869), 375-84, 403-16. Important monographs about war opponents in Iowa and the Midwest include Hubert H. Wubben, Civil War Iowa and the Copperhead Movement (Ames, 1980); and Frank L. Klement, Copperheads in the Middle West (Chicago, 1960).

6. For another case study further suggesting that politics do not hold the key to understanding relief decisions, see Steven J. Buck, "Political and Economic Transformation in the Civil War Era: Du Page County, Illinois, 1830-1880" (Ph.D. diss., Northern Illinois University, 1992). Despite its prowar political orientation, Du Page County handled relief basically the same way as Dubuque, namely, private relief for soldiers, public for families. 
its attention almost exclusively to provisioning work. This came after roughly two years of precariously balancing provisioning with family relief, nearly always to the detriment of the latter. At about the same time, Iowa passed its first law mandating special arrangements for family relief in each county. The law, however, failed to define all soldiers' families as worthy of relief. Local poor relief officers could still give or deny relief based on their perceptions of worthiness. The state relief law, in other words, simply ratified the arrangements for relief as they evolved in Dubuque and elsewhere over the course of the war. $^{7}$

IN THE YEARS BEFORE THE CIVIL WAR, poverty and poor relief were not popular subjects in Dubuque. For one thing, most city leaders believed there was no reason for anyone in Dubuque to be poor. In a pamphlet for the Dubuque Emigrant Aid Society in 1858, for example, lawyer and railroad promoter Platt Smith argued that "a small amount of labor will produce a larger amount of the necessaries of life in the West than in the East." Indeed, Dubuque was even better placed than most western cities, since the city's lead mines were thought to be "inexhaustible," affording work for "thousands" for the foreseeable future. All that was required, added Joseph Dorr, the Democratic editor of the Express and Herald newspaper and a workingman's advocate, was a willingness to work, a determination that "ordinary discouragements shall not dampen your ardor," and individual "enterprise and industry." Dorr added on an-

7. Important sources for Civil War relief in Iowa are John Gillin, History of Poor Relief Legislation in Iowa (Iowa City, 1914), 92-105; and Earl S. Fullbrook, "Relief Work in Iowa during the Civil War," Iowa Journal of History and Politics 16 (1918), 155-274. Gillin argues that "The soldier and his dependents were the first to be exempted from the laws applying to ordinary pauperism; and these exemption laws represent the first real, humane thought given to the subject of poor relief in the history of Iowa" (92). His own account shows, however, that it took three years of prodding by Governor Samuel Kirkwood before the state legislature acted to require family relief. In this, Iowa lagged behind the state of Wisconsin, which at the beginning of the war established a statewide payment of five dollars per month to all soldiers' families. On the other hand, Iowa was ahead of Illinois, which made no statewide provisions for soldiers' families. For other states, see Fish, "Social Relief in the Northwest." 
other occasion that "it will cost but little more to live at prospecting for lead ore, than it will to live idle. ${ }^{18}$

Thus, in Dubuque, as throughout mid-nineteenth-century America, the most common view held that poverty was a product of individual failure and saw the solution in the adoption of the right values, chief among them a simple willingness to work hard. In November 1858 an assistant editor at the Express and Herald provided a catalog of the necessary values. Those "staring [poverty] in the face" should first consider whether "you performed all your duties to yourself and families by honest hard work." Then, "have you, if in work, done your duty to your employer? Have you kept yourselves free from excess and dissipation?" "Overruling Providence," the writer added, "will provide for the honest and industrious." "Self-reliance, and with that a firm reliance on Providence, is all [that is] necessary." Poverty, in this view, resulted from idleness and unwillingness to work, intemperance and immorality, dependence on charity, and lack of faith. ${ }^{9}$

In reality, two groups proved particularly vulnerable to poverty. The first consisted of laborers and their families. As early as 1855, in the midst of the city's great commercial expansion, the Express and Herald suggested the formation of a private poor relief organization. "Incredible as it may seem," the paper reported that November, "there are not wanting in this city, instances of whole families who are suffering the privations of hunger and cold." These were not, however, indolent and dissipated paupers. Rather, they were families of laborers whose jobs disappeared with the coming of winter. The paper was shortly able to report that "sympathy for the distressed has been awakened in many persons," and the "worthy objects of charity" would soon have their suffering alleviated. Similarly, in December 1857, the city launched a program of street repairs "to furnish the heads of families dependent on their daily labor

8. "A Pioneer" [Platt Smith, as identified in the Times, 12 February 1858], Northern Iowa: Containing Hints and Information of Value to Emigrants (Dubuque, 1858), 13-15; Times, 23 August 1858; Express \& Herald, 23 May, 23 June 1858.

9. Express $\&$ Herald, 13 November 1858 . For general discussions of nineteenthcentury views of poverty in America, see note 2. 
for a livelihood, with employment during the Winter." Even during a period of aggressive downsizing of city government during the Panic of 1857, the Times, the consistent voice of the Republican Party in Dubuque during the Civil War era, argued in favor of continuing some public works projects begun by the previous (Democratic) city administration in order to provide employment for the city's working men. ${ }^{10}$

The second group most vulnerable to poverty in prewar Dubuque consisted of female heads of household and their families. Before the Civil War, Dubuque offered few opportunities for women to earn a living, so the absence or death of an adult male wage earner often resulted in poverty for families. In December 1858, for example, the Express and Herald printed fourteen cases of "destitution" turned up in a preliminary survey by a newly formed private relief committee; six of the fourteen cases involved women with children whose husbands had died, gone tramping for work, or deserted the family. A few days earlier, an assistant editor at the paper had taken his own small survey and found six cases of destitution, only two of which had an adult male present and healthy; one case involved three widows and four children sharing a single room. ${ }^{11}$

Further indications of the association between female-headed households and poverty can be gleaned from the 1860 census. Women headed 212 of the 2,726 households in the city in 1860, or almost 8 percent. But of the 936 households without property, 127 , or nearly 14 percent, were headed by females. Looking at the data another way, 60 percent of female heads of household owned no property (127 of 212), compared to only 32 percent of the male heads. Moreover, although the census surely undercounts the number of women earning an income by taking in sewing, laundry, or light manufacturing work, job opportunities for women seem to have been strictly limited. Only 542 of 4,642 women aged 12 and over in the city had occupations listed in

10. Express $\&$ Herald, 29 November, 3 December 1855, 9 December 1857; Times, 14 August 1858 . My understanding of vulnerability to poverty in commercial Dubuque is informed by Stansell, City of Women, esp. 43-46; and Katz, In the Shadow, 4-10.

11. Express \& Herald, 9, 12 December 1858. 
the census; 456 of those had unskilled occupations, mostly as domestic servants (417). ${ }^{12}$

Prewar poor relief in the city relied on both private and public efforts. Private charities focused on "outdoor" reliefaiding the poor in their own homes, as opposed to "indoor" or institutional relief - to the worthy poor. The two most organized relief efforts before the war came during the Panic of 1857 , specifically the winters of $1857-58$ and $1858-59$. In those years, relief committees divided the city into twenty-five districts; for each district a two-person team (one man and one woman) canvassed the need and collected and disbursed supplies to the needy (an additional two-person team covered the area of Julien Township outside Dubuque). In providing outdoor relief, the committees were admonished not "to encourage indolence or vagrancy" and to be sure that they were not "imposed upon by strangers" - that is, they should not help people who moved to Dubuque simply for relief. Nor should they supply the poor with "luxuries" like coffee, but at most "only in part with the bare necessaries." Indeed, the committees' "design" was "to afford partial relief to persons temporarily out of employment or in feeble health." All others, and anyone "with no prospect of doing anything for themselves," were turned over to the public, indoor relief establishments. Poor relief, in other words, was based strictly on worthiness and need; there were no hints at this early day that relief was a right, or entitlement. ${ }^{13}$

Some public funds were also expended for outdoor relief, but most public poor relief efforts took the form of indoor relief at the County Poor House or the City House of Refuge. Both, however, became embroiled in the increasingly turbulent county and city politics of the late 1850 s. Political machinations colored a grand jury indictment of the Poor House in May 1858,

12. 1860 Federal Manuscript Census, Population, Julien Township, Dubuque County, Iowa. For general discussion of women's employment during this period, see Alice Kessler-Harris, Out to Work: A History of Wage-Earning Women in the United States (New York, 1982), esp. 45-72.

13. For comments on what private relief should be doing, see Times, 7, 22 December 1857, 16 November 1858; Express \& Herald, 22 December 1857, 4 December 1858. 
which hampered its ministrations to the poor. ${ }^{14}$ A "People's Reform" Party - a fusion of Republicans and reform-minded Democrats - had just captured the city government, but the Democratic Party remained dominant in the county. One Democrat in particular - former governor of Iowa, now Judge Stephen Hempstead - was thought to rule Dubuque County as a private fiefdom. The attack on the Poor House was thus as much as anything an attempt to expose Democratic corruption and break Hempstead's power. Similarly, the reformers asserted that the City House of Refuge had fallen under the control of holdover Republican councilman Robert Mitton. Arguing that the House of Refuge merely duplicated the function of the Poor House, for which city residents supplied the majority of the tax support, the Reform city council voted to close it. ${ }^{15}$

Apparently only Democratic alderman Michael McNamara saw the attack on the House of Refuge for what it said about the poor and poor relief in Dubuque. The decision to close the house, he declared, showed "no sympathy for the poor." "If one dollar was expended for a poor person," he added, "there was more sympathy for the dollar than for the poor." The attitude condemned by McNamara was further reflected in the Dubuque Emigrant Association's guide published the same year. Its author, Platt Smith, referred to collections for poor relief as "an excessive bore." More evidence of a growing dislike for the poor in Dubuque comes from the tepid response to the private relief committee in the winter of 1858-59. Although the Express and Herald declared the committee's work a success within a few days of its beginning, meetings suffered from spotty attendance; at one meeting only six of the fifty-two people on district committees

14. The indictment was twofold. First, it alleged that the Poor House had become a refuge for pregnant women whose "husbands or paramours" refused to support them. Second, the House was said to help people "who have no claim whatsoever upon the county." In the end the only result was that a few people were expelled from the Poor House. Times, 25 May 1858.

15. Times, 25, 29 May, 15, 21, 24, 27, 31 July, 5 August 1858; Express \& Herald, 25, 27 July 1858. Between 13 April 1857 and the end of June 1858, the city spent $\$ 3,569$ on indoor relief and $\$ 1,910$ on outdoor relief. Times, 27 July 1858 . For a discussion of how politics and reform related to debates over poorhouses in other parts of the country, see Katz, In the Shadow, 25-35. 
attended. One commentator on the 1858-59 work asserted that "beyond reports on destitution we are not aware that anything was done to feed the hungry or clothe the naked." The following winter, no attempt was made to establish a citywide voluntary relief system. "Poor friendless children of poverty," the Herald's Joseph Dorr wrote in December 1859 after seeing two "ragged" little girls "gazing hopelessly" into shop windows at the fine clothes on display, "you ... are pariahs in this goodly city."

The task of poor relief was about to get much larger. Beginning in April 1861, large numbers of Dubuque men left their families, joined the Union army, and went south. Interestingly, one source of female-headed households and poverty before the war was men going south in search of employment. In December 1858, for example, the Express and Herald had reported "not a few families ... in more or less destitution" from this source, because the men found themselves "unable to more than supply their own wants, and of course not able to send means of living to their families." With the coming of the Civil War, the number of families with a male wage earner (or more than one) "gone-South" greatly increased. But because of low pay, delays in receiving it, and difficulties sending it home-if they were so inclined-soldiers, too, had trouble supporting their families. The city's poor relief workers and organizations struggled to find appropriate solutions. ${ }^{17}$

WHEN THE WAR CAME, a group of Dubuque's leading male residents moved quickly to form an organization "to receive and disburse funds for the benefit of families of volunteers." This organization, known as the Volunteer Fund Board (VFB), helped reassure Dubuque's early volunteers that their families would be cared for in their absence. This understanding was sufficient for the first two companies of soldiers who left town

16. Express \& Herald, 8, 14, 17 December 1858, 9 January 1859; "Pioneer" [Smith], .Northern Iowa, 15; and Herald, 21, 29 December 1859. The St. Andrew's Society and the St. Vincent de Paul Society did provide some poor relief during the winter of 1859-60. For nineteenth-century dislike for the poor, see Trattner, From Poor Law to Welfare State, 64-67.

17. Express \& Herald, 4 December 1858. 
on April 23, 1861, for their ninety days of service (which actually extended to closer to 120 days). But the simple fact of the VFB's existence was not enough for members of the third company of Dubuquers. These men would have to commit to serve up to three years as part of the Third Iowa Infantry. Accordingly, the men approached the VFB for additional assurances, saying they would enlist only if the VFB guaranteed help for their families. Eight of the VFB's leading members, including mayor H. L. Stout, banker J. K. Graves, and insurance agent Mathew Allison, signed a statement pledging the VFB and themselves personally to care for the men's families. ${ }^{18}$

Roughly eight months later, the VFB terminated its existence, and with it the pledges to the Third Infantry also expired. Things had started promisingly for the VFB. In May 1861 the pledge total reached $\$ 6,000$, and by that September the VFB had helped sixty soldiers' families in Dubuque's first three companies with about $\$ 1,800$. Twenty-five of those families had no other means of support and received three dollars per week from the VFB. By November 1861, however, the VFB had to ask the county board of supervisors for an appropriation of one thousand dollars to cover its obligations. Then, in January 1862, the organizers announced that after providing $\$ 2,700$ in cash and groceries to 116 soldiers' families, its funds were exhausted. The rest of the pledges - as much as $\$ 4,300$ - could not be collected. Consequently, the VFB disbanded and turned family relief over to the county board of supervisors. ${ }^{19}$

There are several possible explanations for the failure of male voluntary relief efforts. First, the men of the VFB, like the

18. Times, 13 February, 21 April 1861. See also Franklin T. Oldt, History of Dubuque County, Iowa (Chicago, 1911), 261-62; The History of Dubuque County, Iowa (Chicago, 1880), 262, 416-17; and Franc B. Wilkie, The Iowa First: Letters from the War (Dubuque, 1861), 5-6.

19. Oldt, Dubuque County, 264, 270-72; Herald, 14 September, 22 November 1861; Times, 8 January 1862; Helen Wulkow, "Dubuque in the Civil War Period" (M.A. thesis, Northwestern University, 1941), 92. For an indication that Dubuquers' failure to redeem their pledges for soldiers' families was not uncommon (and hence not based merely on partisanship), see Wector, When Johnny Comes. Marching Home, 161-62; and Joseph Allan Frank and George A. Reaves, "Seeing the Elephant": Raw Recruits at the Battle of Shiloh (Westport, CT, 1989), 59. 
volunteers for the First Iowa Infantry, assumed that the war would be short-ninety days, maximum. With VFB pledges collected on a quarterly installment basis, many pledgers probably had not expected to make more than one or two payments. When the enlistments of the First Iowa expired, so, many VFB pledgers thought, did their pledges. Second, the VFB consisted of business men. They had difficulty sustaining their interest in organizations that demanded time, effort, and money, but offered no remuneration-especially during an economic recession such as affected Dubuque early in the war. Third, these were also men in a society that generally saw volunteer benevolent work as part of women's sphere. Finally, the men of the VFB had undertaken that portion of the relief problem which over the course of the war would prove to be the most intractable and least popular - family relief. ${ }^{20}$

Meanwhile, with the men supposedly handling family relief at the beginning of the war, Dubuque's benevolent women turned to provisioning the soldiers in the field. Near the end of April 1861, in response to Governor Samuel Kirkwood's call for the women of the state to sew uniforms for the First Iowa Infantry, they formed a Ladies' Volunteer Labor Society. In late 1861 this society reorganized as the Ladies Aid Society (LAS), with a continuing mission to supply the soldiers' needs in the field. Although its origins were in provisioning work, when the VFB died in January 1862, the LAS began doing what it could for soldiers' families, too. During the next two years, the LAS held various fund-raisers, collected supplies from private individuals, organized sewing circles, forwarded supplies to the field, and tried to ascertain and meet the needs of the families. ${ }^{21}$

20. Herald, 29 August, 9 October 1861; Attie, "Warwork," esp. 249-52. See also Theda Skocpol, Protecting Soldiers and Mothers: The Political Origins of Social Policy in the United States (Cambridge, MA, 1992), 2-3. In the context of comparing European and American welfare systems in the late nineteenth and early twentieth centuries, Skocpol argues that "in the United States, most men were preoccupied with partisan politics or business and 'the initiative in civic matters ... devolved largely upon women' organized into voluntary associations."

21. Times, 30 April, 1, 5 May 1861; Herald, 30 April 1861; Oldt, Dubuque County, 264-65; History of Dubuque County, 418; Wulkow, "Dubuque in the Civil War," 85. For LAS activities, see, for example, Times, 8 January, 2, 4, 6, 9, 26 April, 11 June, 16 August, 11 September, 10, 24 December 1862, 4, 6, 8, 11, 17, 23 
Enthusiasm for involvement in the LAS waxed and waned over these years. With more to do than they could possibly manage, LAS leaders and supporters found that only provisioning work could generate significant enthusiasm. An LAS meeting on April 6, 1862, for example, drew "very few" of the society's 227 members. Two weeks later - after reports of the Battle of Shiloh had reached the city - attendance was "unusually full," and an "increased interest has been manifested by those present." By June 1862, with the Shiloh emergency passed, attendance had again "diminished very much," and according to the Times only "the persevering resolution and constant zeal of a few" kept the society's work alive. ${ }^{22}$

For their part, the leaders of the LAS recognized that family relief was less popular than providing provisions for soldiers. As a result, they emphasized the latter in their public statements. One female contributor to the Times in July 1863, for instance, tried to rally support for the LAS by invoking suffering soldiers and drawing parallels to the women's situation. "Perhaps it seems hard to take the long, warm walk to the place where you are wont to meet. The soldiers that are now suffering, toiled, undaunted, beneath the rays of that Southern sun, without water or food all of that long day, until a cannon ball, sped with unerring aim, caused him to desist." The press tried to help the LAS by regularly admonishing the women of Dubuque that a "true woman" could have no "higher mission" than to join the LAS; it was, in fact, their "duty."23.

Nevertheless, even the most zealous LAS supporters had to allow that as the primary voluntary organization for the relief of both soldiers and their families, the LAS women were overworked. As the Times put it in August 1863, "This Society was formed mainly for the purpose of sending supplies to the

January, 1, 6, 14, 25 February, 7, 15 March, 13 June, 11 July, 1 September, 28 November, 18 December 1863; and Oldt, Dubuque County, 297, 301. The LAS was known variously as the Volunteers' Aid Society or the Soldiers' Aid Society; for consistency, I will use Ladies' Aid Society.

22. Times, 6, 19 April, 11 June 1862.

23. Times, 11 July 1863, 25 June 1861, 11 January 1863. See also Herald, 30 April, 6 November 1861; Times, 29 May 1861, 13 February 1863. 
sick and wounded soldiers, but in the absence of any other organization, they have to procure aid for Soldiers' families." When another relief organization was eventually established in Dubuque in November 1864 - a local "auxiliary" of the national Christian Commission-it clearly stated that its mission extended only to provisioning soldiers in the field. The LAS, meanwhile, kept up with provisioning work, but at the same time it was, members told the Times in August 1863, "overwhelmed with calls for assistance" from soldiers' families. ${ }^{24}$

That the families of soldiers suffered no one could deny. Solon Langworthy, one of Dubuque's early settlers and still among its leading citizens, noticed problems as early as August 1862. "The Families of Soldiers are begging [throughout] the City with less Success then Circus men meet with," he wrote in his diary. "Shame on the Community who Suffer the defenders of the Constitution to Complain that their Families are not Provided for while they are Battling for Liberty + Law." ${ }^{25}$ In January 1864 the Dubuque County Superintendent of the Poor put some numbers to Langworthy's impression. He reported that during 1863 he gave outdoor relief to 243 poor families, nearly half of which (116) were families of absent soldiers. In March 1864 the LAS reported that during the previous four months it had helped "over Eighty Soldiers' Families," with nearly sixty "entirely dependent" on the society. ${ }^{26}$

Analysis of the soldiers found in the 1860 census provides a crude measure of the extent of poverty among their families. Prior to March 1864, the month of the LAS statistics, 409 men enlisted for three years service. Including men who died or had been discharged for disability before the end of March, 115 of those men were married with children, 3 widowers with children, and 18 sons of widowed mothers; another 33 were married in 1860 but without children, although they may have had young children by the time they enlisted (see table). In other

24. Times, 30 August 1863, 21, 23 November 1864; Wulkow, "Dubuque in the Civil War," 91: lowa Religious Newsletter [Dubuque], January 1864, p. 5.

25. Solon M. Langworthy Diary, State Historical Society of Iowa, Iowa City (hereafter SHSI), p. 251; I have rendered an illegible word as throughout.

26. Herald, 26 January 1864; Times, 12 March 1864. 
TABLE

THREE-YEAR VOLUNTEERS PRIOR TO MARCH 1864

\begin{tabular}{lcccc}
\hline \multirow{2}{*}{ Relation to } & \multicolumn{3}{c}{ Marital/Family Status, 1860 } \\
\cline { 2 - 5 } Household Head & \multicolumn{2}{c}{ Single } & \multicolumn{2}{c}{ Married } \\
\cline { 2 - 5 } & $\begin{array}{c}\text { With } \\
\text { Children }\end{array}$ & $\begin{array}{c}\text { Without } \\
\text { Children }\end{array}$ & $\begin{array}{c}\text { With } \\
\text { Children }\end{array}$ & $\begin{array}{c}\text { Without } \\
\text { Children }\end{array}$ \\
\hline Head & 3 & 10 & 110 & 27 \\
Son of male head & 0 & 129 & 1 & 1 \\
Son of female head & 0 & 18 & 0 & 0 \\
All other & 0 & 101 & 4 & 5 \\
\cline { 2 - 5 } Total & 3 & 258 & 115 & 33 \\
& $(0.7 \%)$ & $(63.1 \%)$ & $(28.1 \%)$ & $(8.1 \%)$ \\
\hline
\end{tabular}

SOURCES: 1860 Manuscript Census, Population, Dubuque County; Iowa Adjutant General's Office, Roster and Record of Iowa Soldiers in the War of the Rebellion (Des Moines, 1911); Compiled Service Records, Record Group 94, National Archives, Washington, DC. NOTE: The numbers in the table and in the text exclude six men whose dates and conditions of discharge from the service are unknown.

words, in March 1864 about 169 families were particularly vulnerable, according to the prewar association between poverty and female-headed households. This at a time when over onethird of that number of families (60) were said to be "entirely dependent" on the LAS and over two-thirds (116) had received some outdoor relief from the county during the previous year.

These data offer only a rough approximation, however. They do not, for example, account for mobility into the city between 1860 and the time of enlistment. Thus, for example, William Jones is not included in the data. Although Jones's widowed mother, Margaret, and two younger sisters appeared in the census, he did not. In July 1862 Margaret Jones died, and William moved back to Dubuque to live with his sisters. A month later, he enlisted. He was killed in January 1863. Nor do the data account for other changes in circumstances. Luther Jordan and J. Ambrose Fanning appear in the data as the sons of male heads of household, but their fathers died before they both enlisted in Company F, 21st Iowa Infantry, in August 1862. Hence Jordan and Fanning were, in fact, sons of female heads of household. Finally, the data also miss cases where sons and their widowed mothers lived as boarders in someone else's household. Miner Thomas Guilford of Company A, Third Iowa Infantry, was one of these. Although he appears in the data as 
a single boarder, he lived with and supported his blind mother, Margaret, and younger sister, Dora; like William Jones, Thomas Guilford died in the army. ${ }^{27}$

Jones, Jordan, Fanning, and Guilford all served as privates, earning at most sixteen dollars per month, and one would expect their families to have had difficulty making ends meet. But families of officers suffered as well, even though officers were much better paid. Charles Mackenzie was serving as adjutant of the Ninth Iowa Infantry when he resigned in 1863, claiming that although he left his father in "comfortable circumstances" when he enlisted, "since that time he has become straigened [sic] in circumstances." Six months later, having rectified his parents' situation, Mackenzie returned to the army, only to resign again in January 1865 because his "aged and infirm parents" needed him. Lieutenants Peter M. Brown and Joseph J. Dengl also resigned to better care for "helpless" parents. Volney Curtis, first lieutenant in Company K, Ninth Iowa Cavalry, resigned in 1865 because his wife died. "I have the orphant [sic] children at home dependent on me for support," he wrote, "and at this time they are without a house or any one to look to for protection." ${ }^{28}$

27. Federal Manuscript Census, 1860, Population, pp. 31, 47, 178, and 273; William Jones, 21st Iowa Infantry, and Thomas Guilford, Third lowa Infantry, in Compiled Service Records, Record Group 94, National Archives, Washington, DC; Josiah Conzett, Recollections of People and Events, Dubuque, Iowa, 1846-1890 (Dubuque, 1971), 254-55 (Conzett's Recollections, written in 1905, are held at the Center for Dubuque History, Loras College, Dubuque); Times, 22 April, 17 June 1862, 21, 27 January 1863 . There are two other weaknesses in the data: the data assume that each enlistee came from a different household; and they downplay the possibility that sons of male-headed households may have had elderly parents who were hence vulnerable to poverty in their sons' absence. These two weaknesses may largely cancel each other: the first overcounts, the second undercounts the number of vulnerable families.

28. See letters of resignation in Compiled Service Records of Charles Mackenzie, 9th Infantry; Peter M. Brown, 21st Infantry; Joseph J. Dengl, 3rd Artillery; and Volney Curtis, 9 th Cavalry. For others who refer to family circumstances in resigning, see Compiled Service Records of Edgar Tisdale, 9th Infantry; Henry Meyer, 16th Infantry; Theodore F. Lewis, 5th Cavalry; Nicholas J. $\mathrm{O}^{\prime}$ Brien, 7th Cavalry; James Hill, 21st Infantry; and John W. Scott, 42nd Illinois Infantry. Enlisted men could not resign, but they could apply for furloughs; for some citing family suffering, see Compiled Service Records of Gottlieb Hammer, 5th Cavalry; Arnold Allen, James Scripture, and William Van Horn, 21st Infantry; and John Lampert, 16th Infantry. For officers seeking leaves of 
Accordingly, when soldiers expressed an opinion, they preferred that their families be helped first, before aid societies turned to patriotic provisioning work. Ernst Renner, a farmer from Peru Township in Dubuque County, best summarized the feeling. He and others had hesitated to enlist with the 21st Infantry in August 1862 "because, from previous experience, we feared that our families would be neglected during our absence." Obviously he was thinking about the Dubuque members of the Third Iowa Infantry who had refused to enlist in 1861 until their families' support had been guaranteed, a guarantee that expired when the VFB dissolved in January 1862 . The promise of a fiftydollar bonus, or "bounty," from Dubuque County helped change the enlistees' minds, but within a month of their enlistment, the county board of supervisors restricted bounty eligibility in such a way that some families would not receive the money. Renner wrote that the action had broken that "courage, heart and love [of] home and county [sic] which alone can uphold and strengthen the soldier." ${ }^{29}$

WHILE THE LAS and others went about the business of doing what they could and what they considered appropriate for soldiers and their families, a debate about war relief unfolded in Dubuque. The discussion was political only inasmuch as war supporters favored anything having as its end relief for soldiers, while war opponents occasionally divided on such issues. But neither supporters nor opponents managed to sustain a high level of interest in family relief. In the end, a discussion that had the potential to advance the cause of social welfare in the United States merely facilitated the assimilation of war relief into existing patterns of poor relief. Instead of leading to a reexamination of the assumptions of prewar poor relief, those assumptions were carried into the wartime debate. The soldiers eventually came to be identified with the worthiest poor, while

absence for family reasons; see Compiled Service Records of Nathaniel E. Duncan, 12th Infantry; and George M. Staples, 14th Infantry.

29. Times, 13 September 1862; Ernst Renner, Compiled Service Records, 21st Infantry. See also Herald, 26 January 1864; Times, 12, 13, 16 March 1864; and History of Dubuque County, 262. 
the families - even though their poverty might have been seen as not their own fault - usually found themselves lumped with the unworthy poor.

Serious discussion of war relief might have begun as early as October 1861. Leading war opponent Dennis Mahony, who had taken control of the Herald from his friend Joseph Dorr after the 1860 presidential election, asserted that care for soldiers' families was too important to be left to "the cold voluntary charity of the world," exemplified by the Volunteer Fund Board. Mahony viewed the war through traditional Jacksonian Democratic lenses of class and privilege. For him, the war had already become a "rich man's war and a poor man's fight." Thus Mahony argued that "if needs be, let the superfluous, superabundant wealth of the rich man who remains at his ease at home be taken and used for the support of the families of those who give their lives voluntarily to their country." Furthermore, Mahony declared that if the rich could not be induced to contribute voluntarily, "The Government-we care not whether State or Federal-must impose it as an obligation. .. . Thus will the rich be made to bear some share of the burden of the war." ${ }^{30}$

That suggestion of an increased government role in relief work went nowhere. Three months later, the Volunteer Fund Board collapsed and dropped male relief work into the lap of the county board of supervisors, a body dominated by Democratic opponents of the war. After considering the legality of a special appropriation and tax to pay for aid to soldiers' families, the supervisors rejected that plan. They instead instructed the superintendent of the poor to consider soldiers' families as he did the other poor and to provide aid to the truly needy. Later in 1862, during a major recruiting drive in the fall, the supervisors again discussed arrangements for soldiers' families and decided against a change of policy. The supervisors felt that money from the fifty-dollar county bounty created in the same

30. Herald, 3 October 1861. For specific Democratic criticisms of the VFB, see Herald, 29 August, 9 October 1861. For basic Jacksonian Democrat views, see Sean Wilentz, "Society, Politics, and the Market Revolution, 1815-1848," in Eric Foner, ed., The New American History (Philadelphia, 1990), 51-71. 
session would provide for families until the soldiers' government pay started. A specific appropriation for family relief, in addition to being of questionable legality, would be discriminatory and unnecessarily strain the county treasury, they concluded. ${ }^{31}$

Whether the board's various concerns were valid or not, Republicans used the supervisors' actions to fuel allegations of Democratic disloyalty. The Republican, prowar Times thought the board was more interested in discouraging enlistments than in legality, fairness, or frugality. In a brief comment following the late 1862 decision to offer no special aid for families, the paper's editor, G. T. Stewart, offered a contrast. The supervisors of Polk County in Iowa had appropriated $\$ 3,000$ for soldiers' families in September 1862, levying a property tax of 1 mill to pay for it. "For the same patriotic purpose," Stewart pointed out, the Dubuque supervisors "appropriated nothing." Later, a December 1862 "City News" item signed "How" argued that the supervisors could "clothe their corporate conscience with a clean shirt," first, simply "by becoming patriots" - that is, by unconditionally supporting the war and Republican management of it - and second, "by making an appropriation for the families of soldiers." 32

Still, considering that the supervisors had in effect reduced soldiers' families to the status of paupers, these denunciations seem relatively mild. They were, moreover, rather disingenuous. Although the war opponents on the board of supervisors may have responded as they did in order to disrupt the war effort in the city, few-among even war supporters wanted to dole out money indiscriminately to soldiers' families. That, they feared, would foster mendicancy, dependency, and laziness. Hence, if the board of supervisors stigmatized the soldiers' families by classing them with other poor people, the Ladies Aid Society

31. Dan Elbert Clark, Samuel Jordan Kirkwood (Iowa City, 1917), 194; Oldt, Dubuque County, 284, 286; Wulkow, "Dubuque in the Civil War," 91; Richard Bonson Diaries, 20 August 1862, SHSI. Concerns about legality were unfounded, because in May 1861 the Iowa legislature had specifically authorized county governments to aid soldiers' families out of public moneys. The supervisors chose to place a strict construction on that authorization, concluding that it allowed payments out of existing funds only.

32. Times, 11 September, 21 December 1862. 
treated them similarly, adopting the same "worthy/unworthy" dichotomy that private relief organizations applied to the poor in general. Despite assertions that "to be a soldier's wife is an honor" and that it was "no reproach to be poor," as early as February 1862 the LAS appointed a visiting and "investigating" committee to call on soldiers' families and ascertain their needs and worthiness. In June 1863, for example, the Herald charged that the LAS had refused to help a soldier's family after the wife converted to Catholicism. The LAS denied the charge, claiming instead that they had stopped helping the family because the wife "became utterly unworthy of any further assistance." Once the society learned of the woman's "true character," to continue aid would be "wronging the honest and worthy families of absent soldiers." The prowar Times applauded the LAS's decision. ${ }^{33}$

In both public and private charity, then, soldiers' families were identified with "the poor." They accordingly evoked less interest and sympathy from even war supporters than the soldiers themselves did. Two decisions of the board of supervisors in late 1863 and early 1864 illustrate this. In October 1863, three of the city's leading male residents, including two men openly opposed to the war, approached the supervisors for an appropriation on behalf of a proposed soldiers' home. As the transportation hub of northern Iowa, numerous sick and disabled soldiers passed through Dubuque on their way home. All needed a place to stay, and many needed medical care; the soldiers' home would provide both. The board of supervisors, however, voted 15 to 4 against the appropriation. War opponent Stilson Hutchins explained the decision in the Herald. The board, he argued, had "wisely abstained from making special appropriations" for a private charitable organization, but they "have given the superintendent of the county poor additional instructions for relieving the wants of those in need." "The charity," he added, "will be dispensed to soldiers as freely as to others. ${ }^{134}$

33. Times, 4 February 1862, 21, 23 June, 21 November 1863; Herald, 20 June 1863. See also Herald, 26, 27 June 1863, 16 September 1864; Times, 27 June 1863; and Stephen J. Buck, "'A Contest in which Blood Must Flow Like Water': Du Page County and the Civil War," Illinois Historical Journal 87 (1994), 15-20.

34. Times, 21, 23, 24 October 1863; Herald, 23 October 1863; Wulkow, "Dubuque in the Civil War," 92-93; Oldt, Dubuque County, 302. 
War supporters and proponents of the soldiers' home exploded with all the indignation that had been missing from their response to earlier board actions regarding the relief of soldiers' families. The city council, with antiwar mayor J. $\mathrm{H}$. Thedinga casting the deciding vote, passed resolutions denouncing the board's action as "ungenerous, ungrateful, and unjust ... [meriting] the scorn and contempt of all patriotic men." The council also voted unanimously - war supporters and opponents alike - to appropriate city funds for the soldiers' home. A writer in the Times using the pseudonym "A Friend of "The Home" with them: "The poor, deluded, imbecile, treason stricken traitors, in their rage and hate, supposed they could injure the cause of the their suffering country, by stigmatizing her brave defenders as paupers, returning from the army. This was the aim and purpose of the whole proceeding." The same writer also questioned the supervisors' right to be considered "honorable men," an argument an assistant editor at the Times took a step further when he questioned their claim to be "men."

But when the board of supervisors next met following the soldiers' home decision and passed further ungenerous resolutions, this time with respect to soldiers' families, war supporters responded in a strangely muted fashion. In a decision recalling both an older, eighteenth-century view of poor relief (namely, that communities were responsible for the relief of their own residents only and any other poor could be returned to their community of origin) and the admonishment that relief committees during the Panic of 1857 not be "imposed upon by strangers," the supervisors in January 1864 instructed the superintendent of the poor to help only "such families of soldiers as have enlisted from this county and are placed to its credit as furnishing its

35. Times, 6 November, 27 October 1863, 30 January 1864. The only comparable expression with respect to aid to soldiers' families came from one of the soldiers, Ernst Renner, and that from his letter a year earlier, when the supervisors tried to renege on the local bounty payments that soldiers thought would take care of their families until their government wages started. That action by the supervisors, according to Renner, showed "either the utmost dishonesty or stupidity of that collection of men - men? - no something else." Times, 13 September 1862. 
quota of volunteers or conscripts." The resolutions further stated the supervisors' concern that, in the draft, substitute, and bounty regime then dominating army recruitment, Dubuquers volunteering for the army were going to the credit of other counties and that families of volunteers from other parts of Iowa were relocating to Dubuque. "Dubuque County is sufficiently burdened," the supervisors declared, "with its own poor and ... the destitute families of soldiers, who have enlisted ... to its credit." With this decision, in other words, local families-Dubuque families - were defined as "strangers" who could be denied aid (even if they qualified as paupers) if the soldier had enlisted to the credit of some other county. ${ }^{36}$

In response, the Times declared that this action repeated "the insult" of the soldiers' home decision in October 1863. "In supplying the necessities of the soldiers' families," assistant editor George M. Ballou argued, "we are not contributing to the relief of paupers ... we are paying a debt due those who are absent on the field of battle." In other words, the "debt" was owed not to the families but to the soldiers. The only other reaction was Ballou's repetition of some advice he had given the soldiers six months earlier, namely, to "cherish that hatred," "all the hatred which you can nourish in your hearts," toward the Democrats. That was the extent of the reaction, and even this was directed more at a renewed complaint in the Herald that the LAS did not give its help to all the needy families "without regard to caste, religion, political persuasion, or anything else." ${ }^{\prime 37}$

The contrast is clear. Although most of the soldiers helped by the soldiers' home came from outside Dubuque Countyand all of them lived outside the city of Dubuque - aid to the soldiers' home generated significant, vociferous support. Even war opponents on the city council voted to appropriate money from city taxes to support the home and to denounce the board of supervisors for not doing likewise. On the other hand, sol-

36. Times, 9 January 1864 . For eighteenth-century residency requirements for relief, see Katz, In the Shadow, 13-14; and Himmelfarb, Idea of Poverty, 24-25.

37. Times, 19 January 1864, 23 June 1863; Herald, 17 January 1864 . Ballou was a veteran who had been wounded at Wilson's Creek in August 1861 as a member of the First Iowa Infantry. See George M. Ballou, First Infantry, Compiled Service Records. 
diers' families, even if local, apparently did not have the same claim to the community's generosity. When the political system denied direct aid to some soldiers' families in January 1864, war supporters grumbled a bit, but they did not unleash scurrilous attacks on "imbeciles" of questionable manhood making decisions based on "their rage and hate." And, in January 1865, when the supervisors again withdrew promised aid from the families of soldiers who had received a county bounty-this time $\$ 400-$ war supporters did not react at all. ${ }^{38}$

MORE BROADLY, by the end of 1863 Dubuquers were moving toward a decision on the relative merits of aid to soldiers and their families. Like poor relief generally, war relief efforts came to be seen as instruments of social policy promoting family, work, and domesticity. Leading the way was the New Yorkbased United States Sanitary Commission (USSC), the dominant relief association on the national level. When combined with an effective system for transferring money from soldiers in the field to their families, the USSC thought as early as 1861 that providing food and clothing to soldiers rather than to families would prove most beneficial to both. It would, according to one USSC publication, "preserve [the soldier] from the vices of the camps," because a soldier in the field could "scarcely spend [money] . . . without positive injury to himself." Meanwhile, providing for all the soldiers' needs in the field would leave them more money to send home, thus maintaining the soldiers' "sense of a continuing relation" with their families. In other words, aid to soldiers rather than families promoted middle-class values (thrift, sobriety) among the soldiers and domesticity in their families. It furthermore accustomed soldiers to supporting their families with their wages, a lesson that would make the soldier "a better citizen when he returns to civil life. ${ }^{\prime \prime 39}$

38. Times, 13 January, 5 April 1864, 6 November, 4 December, 27 October 1863; Semi-Weekly Times, 6 January 1865.

39. United States Sanitary Commission, A Report to the Secretary of War of the Operations of the Sanitary Commission, and upon the Sanitary Condition of the Volunteer Army, Its Medical Staff, Hospitals, and Hospital Supplies (Washington, DC, 1861) $42-43$. For poor relief as an instrument of social policy, see note 2. 
Hence there were clear ideological reasons for delivering aid to soldiers in the field rather than to families at home. In part, the underlying ideology was one of class, as the middleand upper-class reformers active in the USSC and in local aid societies such as Dubuque's LAS sought to use relief to make better families and better citizens of the recipients. ${ }^{40}$ On December 13,1863 , for example, the Times reported that a soldier's wife who had been supporting herself and "four or five" children by washing clothes and receiving help from the LAS had just informed the society that she no longer needed their help. It seems that her husband, who had been in the army for more than a year without sending her any of his earnings, had suddenly sent her eighty dollars. Previously "profligate," the man declared in a letter that he had "reformed," saving his money and even earning extra pay - all of which "he thought would enable him to provide for his family." Between his wages and her laundry work, the woman thought the family would not need further assistance. In retelling the story, the Times saved its greatest praise for the wife. "Would to heaven that all who depend upon the governmen [sic] for means of living ... were as honest and self-denying in these troublesome times, as this humble woman." The most worthy poor, in other words, were those who did not want or accept charity; the act of pursuing relief defined one as unworthy. ${ }^{41}$

There was also a strong gender component to this ideology. Supplying relief to families meant helping women independent of their husbands or other "natural supporters. ${ }^{\text {.42 }}$ Accordingly, when in December 1863 Carrie Lovell, a young woman from one of Dubuque's most prominent families, suggested the formation of a new organization - a Ladies' Union League of Iowadevoted exclusively to the relief of the families of deceased or

40. For a discussion of the class composition of Dubuque's LAS, see Johnson, "An Army for Industrialization," 645-47.

41. Times, 13 December 1863. See also Times, 29 June 1864, which applauds a group of Menominee Indians in the 37th Wisconsin Infantry for sending allotments to their families: "Is there a civilized community in Wisconsin that can show a better record?"

42. Times, 28 February 1863. 
permanently disabled soldiers, she took care to distance herself from women's rights advocates. "This is," she insisted, "no Woman's Rights Institution or any thing of that kind." It was not "gotten up by those aspiring to occupy the places of the sterner sex." Lovell also attempted to distance her effort from poor relief. It would not be "charity," she argued, but the payment of "a debt justly due" to the families. After this initial announcement, however, the Ladies' League never reappeared in the public press. Most likely, despite Lovell's assurances, it failed to attract support from a public wary of women's rights, weary of the poor, and not prepared for the implication of relief as an entitlement contained in Lovell's organization. ${ }^{43}$

About the only people ready to see relief as an entitlement were the soldiers and their families. Soldiers generally emphasized the need "to take care of their families first, before we send contributions to them," as an assistant editor at the Times argued in 1864. From the soldiers' perspective, there were three obvious problems with emphasizing aid to them rather than their families. First, soldiers did not receive their pay in a regular and timely fashion. Second, and relatedly, even if soldiers had received their pay on schedule, arrangements for sending it home were spotty at best. No provisions were made for direct payments of the soldiers' wages to their families. In response to pressure from the USSC and Iowa's Senator James Grimes, Congress did pass a law in December 1861 creating an "allotment" system. Under the terms of that law, three agents appointed for each state traveled among their state's soldiers "from time to time" to collect money and send it safely home. But if an agent was not present on paydaywhich could come at any time - soldiers had plenty of ways to spend even several months' pay quickly. Moreover, it was left to officers to decide whether their companies or regiments would participate in the system. Many officers preferred not to bother with allotments and would not cooperate with the agents. Finally, soldiers knew too well the irregularity of pay and the vagaries of the allotment system and wanted the assur-

43. Times, 2 December 1863. 
ance that their families were not suffering while they were away and could do little about it. ${ }^{44}$

Among Dubuque's soldiers, for example, only the members of the 21st Infantry seem to have had regular access to the allotment system, although on at least one occasion each, Dubuque members of the Third Infantry and First and Fifth Cavalries sent allotments home. ${ }^{45}$ But even when soldiers did send money home, it was often insufficient to support their families. John Kuntz, a bricklayer in the 21st Infantry, sent money home regularly, but still his family was found living in "great destitution" in 1863. Edward Nagle, a justice of the peace before the war, tried to resign from the Third Artillery in January 1865 because his family could not live on what he could send home. As long as both Nagle and his son Maurice were in the army, they had been able to support his wife and five other children. But Maurice died in December 1863, and Edward claimed to be hobbling on an injured ankle which left him "crippled for life," thus impairing his future earning ability. As a private with no surgeon's certificate attesting to his injury, Nagle was not allowed to resign, nor was he given a discharge until his unit was mustered out in June $1865 .^{46}$

Ernst Renner, who had his "courage, heart and love [of] home and county" broken in 1862, later also tried to resign from the military to better care for his family. In Renner's case, the decision to emphasize aid to soldiers over aid to families

44. Allan Nevins, The War for the Union, vol. 1, The Improvised War, 1861-1862, (New York, 1959), 236; War Department, The War of the Rebellion: A Compilation of the Official Records of the Union and Confederate Armies, 128 serial volumes (Washington, DC, 1880-1901), ser. 3, 1:764. For a positive assessment of the allotment system, see Philip Shaw Paludan, "A People's Contest": The Union and Civil War, 1861-1865 (New York, 1988), 179; for a more negative view, see Fred A. Shannon, Economic History of the People of the United States (New York, 1934), 392.

45. Times, 21 June, 16 July, 1 August, 30 December 1862, 10 January, 22 February, 8 May, 17 July, 3, 8 November 1863, 10, 12 January, 11, 14 June, 6 July 1864.

46. Times, 24 October 1863; Nagle to Maj.-Gen. J. J. Reynolds, 23 January 1865, in Edward Nagle, 3rd Artillery, Compiled Service Records. For other publicized cases of destitution, see Times, 2 March, 27 May, 19 July 1862, 3 January, 12 February, 8 July 1864. 
had the opposite of the intended consequence: it weakened his family relationship and made him a thief. "My wife and family were against my becoming a soldier," he wrote in a letter of resignation in 1864, "and subsequent privations seem to have further alienated them from me." His resignation was not accepted, but he was given a twenty-day leave of absence. Then in January 1865 he was arrested for drawing pay "twice for the same [pay] period which," according to his commanding officer, "could not of been by mistake." This time Renner was allowed to resign quietly rather than face a court martial. ${ }^{47}$

That Renner found himself in this situation may have been the result of developments in relief work in Dubuque during 1864. In January a group of men in Dubuque proposed that the LAS hold a "large scale entertainment" to raise money and vegetables to send to the army. The women of the LAS rejected this notion, arguing that between their current projects on behalf of soldiers and their responsibility as essentially the only private organization providing any family relief, they "had now on hand all they could possibly attend to." Then, at the beginning of March 1864, Mary Livermore of the Chicago branch of the USSC spoke in Dubuque. Her speech helped redirect relief work in the city more exclusively toward soldier relief. In the wake of her visit, war supporters and opponents alike joined in planning for a Northern Iowa Sanitary Fair in Dubuque. The sanitary fair soon absorbed all the efforts of the LAS, leaving the families one less option outside the public poor relief system. ${ }^{48}$

47. Times, 12 March 1864; History of Dubuque County, 262; Times, 13 September 1862; Ernst Renner, 21st Infantry, Compiled Service Records. Six months after he left the army, Renner sold his 175-acre farm, perhaps indicating the strain military service placed on his personal financial situation and the suffering his family endured. Semi-Weekly Times, 20 June 1865.

48. Times, 14, 15, 17 January, 12, 13, 16 March 1864. For an example of the mixed political support for the sanitary fair, see the membership of the finance committee as announced in the Times, 27 March 1864. The fair's treasurer was war opponent J. H. Thedinga, and the 39 committee members included at least eleven other war opponents; the politics of all 39 cannot be determined. Among the opponents on the committee was John Rugamer, who, as a member of the board of supervisors, had in January 1864 supported withdrawing aid from families of local men who enlisted outside Dubuque County, and who in January 1865 authored the resolution denying further aid to families of volunteers who received the $\$ 400$ county bounty. 
On its face, the fair was an overwhelming success. With no individual contributions of more than one hundred dollars, the fair raised $\$ 86,000$ - only $\$ 4,000$ less than a similar fair held in Chicago a year earlier. But from another perspective, the fair was a failure. Although it generated renewed enthusiasm for patriotic provisioning work, that enthusiasm did not extend to family relief. A subscription paper soliciting donations for family relief that began circulating that March had attracted only $\$ 350$ after two months; this at a time when the LAS was helping eighty families and had sixty "entirely dependent" on it. In contrast, it took just six days after Livermore's speech to raise one thousand dollars for provisioning soldiers, and the total kept climbing thereafter. The sanitary fair also absorbed all the attention of Dubuque's benevolent community; even private organizations involved in non-war-related poor relief stopped those efforts in order to concentrate more fully on the fair. Furthermore, on the evening of Livermore's speech, Dubuque's LAS, which like many Iowa relief organizations had remained independent of the USSC, voted to ally with the national organization, thereby committing itself primarily to aid to soldiers, not families. ${ }^{49}$

Thereafter it proved more difficult than ever to mobilize the local benevolent community on behalf of soldiers' families. By November 1864, despite its clearer emphasis on provisioning work, attendance at LAS meetings averaged about ten members. Lingering doubts about the LAS's mission may have contributed to the formation of a local Christian Commission Auxiliary that month with more than one hundred participants - men and women, many of the latter former LAS activists. The Christian Commission left no doubt that its mission extended to provisioning only. Another LAS subscription paper for family relief

49. Donations and Treasurer's Report of the Northern lowa Sanitary Fair, June 1864, Center for Dubuque History, Loras College, Dubuque; Fullbrook, "Relief Work," 245-46; Times, 13, 17, 20 March, 21 May 1864. For the independence of Iowa relief organizations, see Fullbrook, "Relief Work," 212-35; Leonard, Yankee Women, 51-103; and Frederick Law Olmsted to Rev. George Magoun, 6 February 1862, in The Papers of Frederick Law Olmsted, vol. 4, Defending the Union: The Civil War and the U.S. Sanitary Commission, 1861-1863 (Baltimore, 1977), 260-66. 
that month netted just $\$ 700$ and two cords of wood, and at Thanksgiving, the LAS had insufficient resources to provide its usual dinner for the soldiers' families. The organization reported that unless individual Dubuquers stepped into the breach and adopted a family, as many as one hundred soldiers' families would "pass an enjoyless Thanksgiving day." At Christmas, Dubuquers "entirely forgot" the families of soldiers, while spending more on gifts "than at any other Christmas time in [the city's] history, with the exception of the Christmas of '56." Fortunately, the LAS had "a little money in the Treasury" on this occasion, which it used to supply Christmas dinners. The soldiers' children were given gifts "plucked" from their Sunday School Christmas trees; those not in Sunday School apparently received nothing. ${ }^{50}$

Actions by the state government in March 1864 completed the pauperization of soldiers' families. For the previous three years of the war, the state legislature had studiously ignored Governor Samuel Kirkwood's repeated calls for some systematic legislation on behalf of soldiers' families. Instead, it limited its action to authorizing local governments to take whatever steps they deemed necessary and appropriate for family relief. That legislation, however, did not require local governments to take any action. At the same time, during the first three years of the war, the state legislature had passed several laws giving the governor authority to expend public moneys for relief of soldiers in the field, and it appointed two paid relief agents to travel among the soldiers. No agents were paid to ascertain the families' needs. ${ }^{51}$

In his final state-of-the-state address in January 1864, Governor Kirkwood made one last appeal for state action. After noting that arrangements for provisioning soldiers were "well arranged and systematized," he argued that the same could not be said of family relief. He therefore urged the state legislature to adopt "some systematic mode of furnishing aid to the needy families of our soldiers." Finally, in March 1864, the legislature

50. Times; 13, 17 March, 21 May, 17, 21, 23 November, 27 December 1864.

51. Fullbrook, "Relief Work," 248-51; 1861 Laws of Iowa (extra session), 3, 31; 1862 Laws of Iowa, 7-8, 72; ibid. (extra session), 37-39, 47-48. 
responded, mandating that counties levy a minimum property tax of two mills to create local "Relief Funds" for the families. The law placed strict limits on eligibility; it did not define all soldiers' families as eligible - or "worthy" - by virtue of having a husband, father, son, or brother in the military. Relief, in other words, was not a right or entitlement for these families; it continued to be based on estimates of worthiness. The law made local officials responsible for compiling lists of families and determining need. In practice this task likely fell to the local poor relief officer, as it did in Dubuque. ${ }^{52}$

Accordingly, although Dubuque County had been singled out for criticism during the discussion of the Relief Law for treating soldiers' families as "common paupers," the law in effect ratified what Dubuque had been doing and extended it to the rest of the state. Henceforth, although there would be a special fund for soldiers' families, they would have to apply to their local poor relief agency and be evaluated for their worthiness, the same as any other poor people seeking relief. At the end of the year, Governor Kirkwood's successor, William Stone, tried to soften the law's impact, urging that the families not be subjected "to a lynx-eyed scrutiny of [their] circumstances and means," which would be equivalent to "degrading them to pauperism." On the other hand, even Stone, himself a veteran, was not prepared to define the families as automatically "worthy" of aid. "Appearances and general repute" could and should be used, Stone argued, to separate the worthy from the unworthy. ${ }^{53}$

At the end of the war, veteran George Ballou, then an assistant editor at the Times, made one final appeal on behalf of the families of Dubuque's soldiers, calling their relief "a duty of the hour." But Ballou made it clear once more that the "duty" was owed more to the soldiers than to their families. Dubuquers needed to demonstrate their gratitude "to the soldiers who have saved our Government for us." The image Ballou invoked of the families was, by contrast, most unflattering. The LAS, he wrote, was "averse to begging for any more money for these families."

52. Times, 15 January 1864; 1864 Laws of Iowa, 99-101. See also Gillin, History of Poor Relief, 93.

53. Times, 30 January, 7 December 1864. 
Moreover, despite "harrowing" "scenes of want and wretchedness," the most commendable families were those "absolutely suffering" but who "would only consent to accept enough to keep life in themselves." Although Ballou did not specifically invoke the idea of the soldiers as the "natural supporters and protectors" of women and children, others did, and it was clear that even for Ballou, a sometime voice for family relief, the Civil War did not lead to a reconsideration of the "natural" order of things. Women and children should rely on adult males for their support. Neither private charities nor the state should intrude on that dependency - not even for so deserving a group as the families of soldiers. ${ }^{54}$

POST-CIVIL WAR POOR RELIEF reflected the decisions made during the war. Analysis of poor relief in the postwar period reveals, as one scholar puts it, "three persistent patterns": the abandonment of public outdoor relief, the establishment of state boards of charities to administer state institutions and to study the problem of poverty, and, in private charity, the formation of charitable organization societies designed to unite fragmented local relief efforts under larger umbrella organizations. Postwar relief work also continued the prewar belief that poverty resulted from individual (moral) failure and that charity, by breeding dependency, caused poverty. Even disabled veterans, many thought, should be encouraged to turn to their "natural reliances" - their families - in times of need, rather than to the government or charities; barring that, at the end of the war the United States Sanitary Commission advocated the creation of "industrial military asylums" in every state to put the disabled to work. Taken together, these developments formed the outlines of the "scientific philanthropy" that dominated relief work in the final third of the nineteenth century in the United States. The overall purpose

54. Semi-Weekly Times, 23 May 1865; Times, 28 February 1863; Iowa Religious Newsletter, August 1865, 7. 
of such work has been described as being "to regulate and shape the values and behavior of the poor." ${ }^{155}$

It did not have to be this way. Examination of the circumstances of the families of Civil War soldiers might have broken through the notion that the poor were to blame for their own circumstances. War relief might also have prompted the rethinking of a system that left women dependent upon men. Instead, these possibilities were ignored. One of the leading national figures in postwar scientific philanthropy summarized its purpose this way: "The great lesson we want to teach people is to depend on themselves," and by implication their families. Despite occasional assertions that aid to soldiers' families was "a duty of the hour" and the payment of "a debt justly due," Civil War relief taught soldiers and their families a similar lesson. ${ }^{56}$

55. For discussion of postwar trends, see Raymond A. Mohl, "The Abolition of Public Outdoor Relief, 1870-1900: A Critique of the Piven and Cloward Thesis," in Walter I. Trattner, Social Welfare or Social Control? Some Historical Reflections on Regulating the Poor (Knoxville, TN, 1983), 35-47 (quotations from 39, 40, and 47); and Katz, In the Shadow, 58-84. For links between the USSC and the COS movement, see Fredrickson, Inner Civil War, 211-15; and Trattner, From Poor Law to Welfare State, 75-82. The postwar view of disabled veterans comes from Richard Severo and Lewis Milford, The Wages of War: When America's Soldiers Came Home - From Valley Forge to Vietnam (New York, 1989), 135; and, for the USSC idea about "industrial asylums," Iowa Religious Newsletter, June 1864,5 . Interestingly, in Iowa at least, the one group exempted from the workings of scientific philanthropy was soldiers' widows; if they became dependent on public relief, an 1868 law said they could not be institutionalized without their consent. See Gillin, History of Poor Relief, 97-99.

56. The summary of scientific philanthropy's purpose is from Josephine Shaw Lowell, a former USSC worker active in New York's COS after the war; quoted in Mohl, "Abolition of Outdoor Relief," 44. 
Copyright of Annals of Iowa is the property of State of Iowa, by \& through the State Historical Society of Iowa and its content may not be copied or emailed to multiple sites or posted to a listserv without the copyright holder's express written permission. However, users may print, download, or email articles for individual use. 